\begin{tabular}{c} 
DARMABAKTI CENDEKIA: \\
Journal of Community Service and Engagements \\
www.e-journal.unair.ac.id/index.php/DC \\
\hline
\end{tabular}

\section{SOCIALIZATION AND TOURISM AWARENESS TRAINING FOR MANAGERS AND RESIDENTS OF COMMUNITIES AROUND AROSBAYA CRETACEOUS TOURISM OBJECT MADURA}

\section{SOSIALISASI DAN PELATIHAN SADAR WISATA BAGI PENGELOLA DAN WARGA MASYARAKAT SEKITAR OBYEK WISATA BUKIT KAPUR AROSBAYA, MADURA}

\author{
Upik Dyah Eka Noviyanti', Nuruddin ${ }^{2}$ \\ ${ }^{1}$ Department of Business, Faculty of Vocational Studies, Universitas Airlangga, Surabaya-Indonesia \\ ${ }^{2}$ Department of Business, Faculty of Economy and Business, Universitas Airlangga, Surabaya-Indonesia
}

\section{$A B S T R A C T$}

Background: Arosbaya Limestone Hill has now become one of the alternative developing tourist attractions in Madura. The shape of the hill that has sculptures from the rest of the limestone quarry with unique shapes and the red color of the hill blushed into a uniqueness that invited many tourists to this destination. Besides that, its location is easily accessible and not far from other tourist destinations, namely the grave religious site of the Bangkalan Kings "Mother's Tears" which incidentally are already well-known making the potential of this destination developed quite large. Purpose: The purpose of this activity is to increase the understanding and ability of both managers and residents around the Arobi Kapur Hill attractions in Berbeluk Village Arosbaya District Bangkalan Madura Regency on how to manage a tourist destination. Methods: awareness raising and tourism awareness training in the form of awareness of tourism awareness concepts and Sapta Pesona Wisata, tourism management training and excellent service. Results: From the results of the socialization and training, the manager and the community around the Bukit Kapor Arosbaya tourism object can get attention and gain knowledge and skills regarding aspects in the management and management of attractions. Conclusion: Partners get increased knowledge and skills in managing a destination. So that his hope through this program creates economic independence of citizens, especially young people through the field of tourism, the availability of new jobs for residents, and the availability of sustainable management of attractions.

\section{$A B S T R A K$}

Latar Belakang: Bukit Kapur Arosbaya kini sudah menjadi salah satu alternative tempat wisata yang sedang berkembang di Madura. Bentuk bukit yang memiliki bekas pahatan sisa penambangan kapur dengan bentuk-bentuk unik dan warna bukit yang merah merona menjadi keunikan yang mengundang banyak wisatawan ke destinasi ini. Disamping itu letaknya yang mudah terjangkau dan tidak jauh dengan destinasi wisata lain yaitu situs religi makam para Raja Bangkalan "Air Mata Ibu" yang notabene sudah terkenal membuat potensi destinasi ini dikembangkan cukup besar. Tujuan: Tujuan dari kegiatan ini adalah untuk meningkatkan pemahaman dan kemampuan baik pengelola dan warga di sekitar obyek wisata Bukit Kapur Arosbaya Desa Berbeluk Kecamatan Arosbaya Kabupaten Bangkalan Madura tentang bagaimana mengelola sebuah destinasi wisata. Metode: sosialisasi dan pelatihan sadar wisata berupa sosialisasi konsep sadar wisata dan Sapta Pesona Wisata, pelatihan manajemen wisata dan pelayanan prima. Hasil: Dari hasil sosialisasi dan pelatihan dapat diperhatikan pengelola dan masyarakat di sekitar obyek wisata Bukit Kapor Arosbaya mendapatkan pengetahuan dan ketrampilan mengenai aspek aspek dalam pengelolaan dan pengelolaan obyek wisata. Kesimpulan: Mitra mendapatkan peningkatan pengetahuan dan keterampilan dalam pengelolaan sebuah destinasi. Sehingga harapannya melalui program ini tercipta kemandirian ekonomi warga khususnya para pemuda melalui bidang pariwisata, tersedianya lapangan pekerjaan baru bagi warga, dan tersedianya pengelolaan objek wisata yang berkelanjutan.

\section{Scope:}

Social economy

\author{
ARTICLE INFO \\ Recieved 5 November 2019 \\ Accepted 15 Desember 2019 \\ Online 28 Juni 2020 \\ *Correspondence (Korespondensi): \\ Upik Dyah Eka Noviyanti \\ E-mail: \\ upikdyah@vokasi.unair.ac.id
}

\section{Keywords:}

Socialization; Training;

Assistance; Excellent service
Kata kunci:

Sosialisasi; Pelatihan; Sadar Wisata; Pelayanan Prima 


\section{PENDAHULUAN}

Pariwisata di Indonesia merupakan industri yang berkembang pesat. Pertumbuhan pariwisata merupakan pemasukan keempat negara terbesar selain minyak dan gas, kelapa sawit serta lateks (Kementrian Pariwisata Dan Ekonomi Kreatif Republik Indonesia, 2012). Pertumbuhan pariwisata Indonesia sangat signifikan, bahkan menteri pariwisata dan ekonomi kreatif menyatakan bahwa pertumbuhan pariwisata lebih tinggi dari pertumbuhan ekonomi Indonesia secara keseluruhan (Prihatiyani, 2012). Pertumbuhan pariwisata di Jawa Timur juga tak kalah pesat. Jumlah kunjungan wisatawan mancanegara ke Jawa Timur tahun 2014 sebesar 217.193 jiwa.

Meskipun pemerintah Indonesia menekankan pembangunan pariwisata sebagai salah satu prioritas sektor pembangunan, pendekatan ini belum diterapkan secara konsisten di seluruh wilayah. Di Madura, hanya terdapat sedikit kegiatan pariwisata (Dinas Pariwisata Propinsi Jawa Timur, 2007). Hal ini terlihat misalnya dari jumlah akomodasi di Bangkalan dan Sampang pada tahun 2005 dan 2007 jumlahnya sama. Sementara itu di Kabupaten Pamekasan hanya ada sedikit peningkatan dari 10 buah menjadi 11 buah. Sedangkan di Kabupaten Sumenep peningkatan usaha akomodasi sejumlah 5 buah menjadi 7 buah (Dinas Pariwisata Propinsi Jawa Timur, 2007). Pulau Madura dianggap sebagai tujuan wisata yang paling tidak popular di Jawa Timur baik bagi wisatawan luar negeri dan wisatawan domestik. Menurut data kedatangan wisatawan internasional di Pulau Madura sangat rendah. Misalnya, pada tahun 2007, Kabupaten Bangkalan, Kabupaten Sampang dan Kabupaten Sumenep hanya menerima 164, 116, dan 51 wisatawan luar negeri, sementara tidak ada seorang wisatawan asingpun yang mengunjungi Kabupaten Pamekasan (Dinas Pariwisata Propinsi Jawa Timur 2007).

Kabupaten Bangkalan yang letaknya berdekatan langsung dengan Surabaya, merupakan salah satu kabupaten administrative di Pulau Madura selain tiga kabupaten yang lainnya yaitu Bangkalan, Sampang dan Sumenep. Kabupaten Bangkalan sudah memiliki banyak destinasi wisata yang terkenal baik dikancah local maupun nasional. Kabupaten Bangkalan memiliki lebih dari 14 jumlah objek wisata yang berada dalam naungan Dinas Pemuda Olahraga Kebudayaan dan Pariwisata Kabupaten Bangkalan yang terbagi dalam beberapa kategori yaitu pertama wisata alam, seperti Gunung Geger, Api Alam Konang, Kolla Lagundih, Paintai Maneron, Pantai Rongkang, dan Pantai Siring Kemuning. Kedua wisata religi,meliputi Makam Air Mata Ibu, Makam Sultan Abdul Kadirun, dan Makam Syaikhonan
Kholil. Ketiga wisata kuliner, seperti Topa' Ladhah, Tajin Sobih, Emping Mlinjo, Soto Sate, dan Leppet, kuliner Kabupaten Bangkalan juga menawarkan makanan khas tradisional dengan cita rasa modern, seperti bebek sinjay, bebek bengal, dan bebek songkem. Keempat wisata budaya, seperti Kerapan Sapi, Museum Cakraningrat, Mercusuar, dan Situs Benteng Kolonial. Kelima wisata minat khusus, meliputi Batik Tanjung Bumi, Kerajinan Clurit, Kerajinan Pecut dan Taman Rekreasi Kota.

Disamping obyek wisata yang sudah disebutkan di atas masih ada beberapa obyek wisata yang belum masuk dibawah naungan Bidang Pariwisata Disporabudpar Kabupaten Bangkalan. Belum adanya penetapan secara de facto oleh pemerintah setempat, tekait Bukit Kapur Arosbaya ini sebagai obyek wisata, sehingga perhatian pemerintah masih minim. Salah satunya adalah Bukit Pelalangan atau yang dikenal dengan Bukit Arosbaya terletak di Desa Berbeluk, Kecamatan Arosbaya, Kabupaten Bangkalan. Desa Berbeluk sendiri terbagi menjadi enam dusun yaitu dusun Palebunan Barat, dusun Palebunan Timur, dusun Berbeluk Barat, dusun Berbeluk Timur, dusun Pancor dan dusun Pejiran.

Meskipun sudah menjadi obyek wisata yang cukup terkenal namun pengelolaan obyek wisata ini masih cukup sederhana. Obyek Wisata Bukit Kapur Arosbaya sebenarnya memiliki potensi yang besar tetapi karena pengetahuan pengelola dan masyarakat di sekitarnya masih rendah mengakibatkan obyek wisata Bukit Kapur Arosbaya susah untuk berkembang lebih besar. Hal ini terlihat dari Infratsruktur yang belum memadai yaitu belum lengkapnya sarana prasarana pendukung wisata di Bukit Arosbaya mulai dari toilet, mushola, kios dagang, kuliner, penginapan dan sebagainya. Padahal tersedianya sarana dan prasarana yang memadai seperti, kemudahan akses menuju objek wisata, keamanan yang baik saat melalukan perjalan menuju lokasi objek wisata maupun saat berada di lokasi wisata, tersedianya berbagai fasilitas wisata yang dibutuhkan wisatawan akan bisa membangun rasa puas dan menjadikan wisatawan yang berkunjung ingin datang kembali di lain waktu. Keamanan dan keselamatan yang belum terjamin bisa dilihat dari masih adanya praktik pungutan liar menuju Bukit Arosbaya yang membuat pengunjung kurang nyaman berwisata.

Oleh Karena itu, perlu diadakan kegiatan sosialisasi dan pelatihan terkait pengelolaan destinasi wisata bagi pengelola dan masyarakat di sekiat obyek wisata Bukit Kapur Arosbaya. Sehingga pengelola dan warga masyarakat memiliki peningkatan pengetahuan dan skill untuk mengelola obyek wisata di wilayahnya. 


\section{METODE}

Metode kegiatan dalam upaya peningkatan pengetahuan dan skill pengelolaan obyek wisata di sekitar Bukit Kapur Arosbaya ini dilaksanakan dalam tiga tahap yaitu tahap koordinasi dan sosialisasi, Focus Grup Disciussion (FGD) dan pelatihan. Metode kegiatan sosialisasi dan pelatihan terkait pengelolaan obyek wisata ini dilakukan dengan beberapa tahap.

\section{Tahap koordinasi dan sosialisasi kegiatan (3 Agus- tus-3 September 2019)}

Kegiatan diawali dengan survey lokasi untuk kegiatan sosialisasi dan pelatihan sadar wisata di Bukit Arosbaya, Kecamatan Arosbaya, Kabupaten Bangkalan (Gambar 1). Setelah itu dilanjutkan koordinasi dengan perangkat Desa Berbeluk dan BUMDES (Gambar 2). Selanjutnya dilakukan diskusi terkait rencana kegiatan sosialisasi dan pelatihan sadar wisata yang akan dilakukan kemudian dilaksanakan sosialisasi kegiatan \& pelatihan.

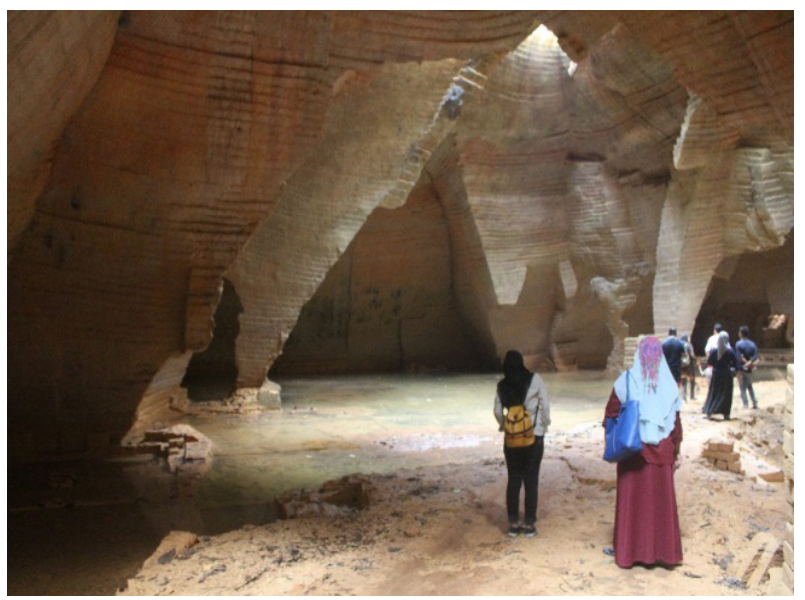

Gambar 1. Kegiatan Survei Kondisi Obyek Wisata Bukit Kapur Arosbaya

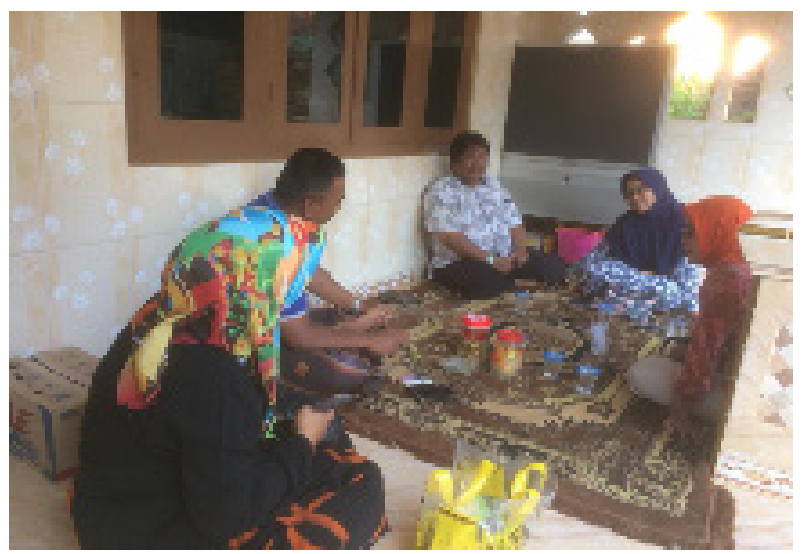

Gambar 2. Kegiatan Koordinasi dengan Pemerintah Desa dan Pengurus BUMDES

Kegiatan Focus Group Discussion (FGD) (12-13 Juli 2019)
Dalam Kegiatan FGD yang telah dilakukan pada 23 September 2019, para perwakilan masyarakat yang terdiri dari unsur tokoh masayarakat, tokoh pemuda, tokoh agama, Bumdes, Kelompok Sadar Wisata (Pokdarwis), PKK, Kelopok perempuan dan anggota masyarakat lainnya diundang dalam kegiatan FGD. Dalam FGD tersebut dipantik oleh Akademisi dari Universitas Trunojoyo Madura (UTM) yaitu Dinara Maya Jilijanti, S.Sos, M.Si (Gambar 3). Acara FGD dimulai oleh dengan pengantar berupa penjelasan tentang maksud dan tujuan dari diadakannya FGD ini. Dimana tujuan FGD ini ingin mengetahui dan menggali aspirasi dari masyarakat dan pengelola obyek wisata Bukit Kapur Arosbaya untuk bisa lebih dikembangkan ke depannya. Berbagai hal yang digali dalam FGD tersebut yaitu potensi Wisata Bukit Kapur Arosbaya, Fasilitas dan Infrastruktur di Obyek wisata Bukit Kapur Arosbaya, Berbagai masalah, tantangan yang dihadapi oleh obyek wisata Bukit Kapur Arosbaya, Kebijakan Pemerintah terkait Obyek Wisata Bukit Kapur Arosbaya, Analisa Kekuatan (Strenght), Kelemahan (Weaks), Peluang (Opportunity) dan Analisa Tantangan (Threat)/SWOT Obyek Wisata Bukit Kapur Arosbaya serta Strategi bagi pengembangan Bukit Kapur Arosbaya.

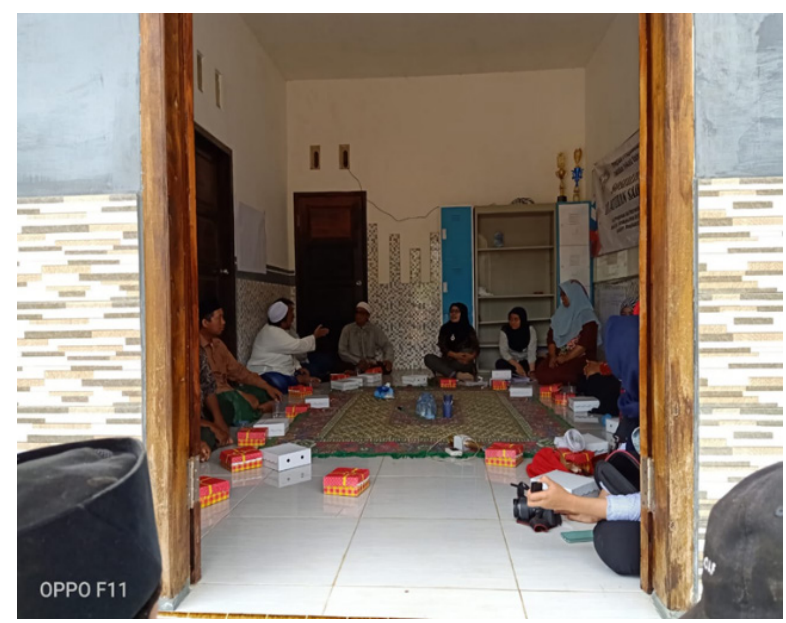

Gambar 3. Kegiatan FGD bersama tokoh dan perwakilan warga Desa Berbeluk

\section{Kegiatan Sosialisasi dan Pelatihan Sadar Wisata (13-27 Juli 2019)}

Sebelum dilaksanakan kegiatan utama, tim pelaksana melakukan koordinasi dengan pemerintah desa terkait pelaksanaan kegiatan. Undangan pelaksanaan kegiatan sosialisasi dan pelatihan sadar wisata disebarkan kepada target kegiatan.Kegiatan sosialisasi dan pelatihan sadar wisata dilaksanakan dengan target pemuda di Desa Berbeluk 


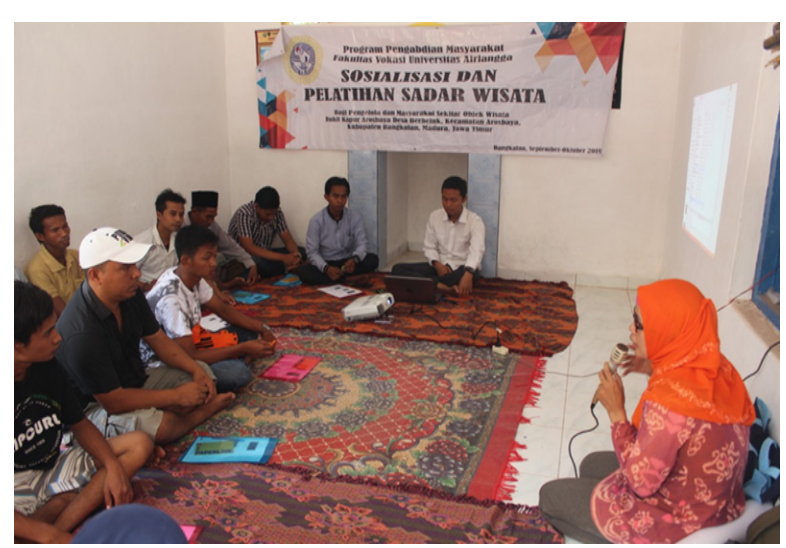

Gambar 4. Kegiatan Sosialisasi dan Pelatihan Sadar Wisata Bagi Pemuda Desa Berbeluk

\section{HASIL DAN PEMBAHASAN}

\section{Gambaran Sosial Masyarakat Desa Berbeluk}

Bukit Arosbaya adalah sebuah obyek wisata yang memiliki potensi cukup besar untuk dikembangkan. Pahatan yang unik bekas penambangan kapur dan warna bukit yang kecoklatan menjadikan daya Tarik tersendiri untuk wisatwan datang berkunjung dan mengabadikan momen dan keindahan bukit Arosbaya ini. Maka tak mengherankan jika bukit Arosbaya ini menjadi destinasi yang cukup diminati saat berkunjung ke Kabupaten Bangkalan.

Selama ini pengelola dan masyarakat di sekitar Bukit Arosbaya belum memiliki kesadaran akan potensi wisata yang cukup besar untuk dikembangkan. Sadar wisata masyarakat yang masih kurang. Warga masih terkesan acuh dan belum serius dengan potensi wisata Bukit Kapur Arosbaya yang ada di Desa Berbeluk yang jika dikelola dengan baik akan menjadi sumber alternative untuk bisa meningkatkan ekonomi warga desa Berbeluk sendiri. Hal ini sesuai dengan tujuan kepariwisataan yang telah diamanatkan oleh Undang-Undang yaitu dalam Undang-Undang Nomor 10 Tahun 2009 tentang Kepariwisataan. Dimana tujuan kepariwisataan diantaranya adalah untuk meningkatkan pertumbuhan ekonomi; meningkatkan kesejahteraan rakyat; menghapus kemiskinan; untuk mengatasi pengangguran, melestarikan alam, lingkungan, dan seumber daya; memajukan kebudayaan; mengangkat citra bangsa; memupuk rasa cinta tanah air; memperkukuh jati diri dan kesatuan bangsa; mempererat persahabatan antar bangsa.

Kesadaran yang masih rendah terhadap potensi Bukit Arosbaya untuk dikembangkan juga terlihat dari belum adanya organisasi yang menaungi seperti Kelompok Sadar Wisata (Pokdarwis) di masyarakat sekitar objek wisata. Obyek wisata Bukit Kapur Arosbaya masih ditangani dan dikelola oleh beberapa warga dan pegiat saja.Para pemuda di Desa Berbeluk yang jumlahnya cukup besar belum memiliki rasa Sadar Wisata di desanya sebenarnya sangat potensial untuk mengembangkan ekonomi kreatif dan pariwisata di desa ini.

\section{Pelaksanaan Program Sosialisasi dan Pelatihan}

Saat pelaksanaan program terlihat antusiasme warga dan pemuda di Desa Berbeluk cukup besar. Hal ini bisa dilihat dari keaktifan mereka dalam mengikuti rangkaian kegiatan. Dalam Tahap Koordinasi dan Perencanaan Kegiatan, pihak pemerintah desa Berbeluk sangat tanggap dan menyambut baik adanya kegiatan tersebut. Pihak pemerintah desa, pemuda dan BUMDES siap membantu mensukseskan kegiatan sosialisasi dan pelatihan sadar wisata. Bahkan, kepala desa berharap bahwakegiatan sepertiinibisa dilanjutkan dengan pelatihan tentang kepariwisataan yang lainnya sehingga pengetahuan masyarakat lebih mumpuni dan semakin siap mengelola obyek wisata Bukit Kapur Arosbaya.

Selain kegiatan formal, beberapa kali pertemuan informal untuk melakukan koordinasi baik terkait tentang teknis pelaksanaan acara maupun koordinasi mengenai materi pelatihan dilakukan. Tim Pengabdian Masyarakat melakukan beberapa kali kunjungan informal dan dijadikan sebagai waktu untuk menjelaskan dan memberikan pemaparan materi baik pada pengelola maupun masyarakat di sekitar obyek wisata Bukit Kapur Arosbaya. Kunjungan informal tersebut juga bertujuan untuk menjalin keakraban dan kedekatan dengan warga masyarakat. Keakraban terlihat saat kunjungan informal melalui pertanyaan pertanyaan yang diajukan masyarakat terkait materi yang akan diberikan.

Kunjungan langsung ke Bukit Kapur Arosbaya juga dilakukan oleh tim pengabdian masyarakat yang didampingi oleh warga masyarakat dan pihak pengelola pada saat kunjungan informal. Hal ini dilakukan untuk mengetahui kondisi secara langsung obyek wisata Bukit Kapur Arosbaya. Dari kunjungan tersebut dilakukan diskusi informal terkait dengan kondisi Bukit Kapur Arosabaya, Masalah yang dihadapi, Bagaimana tata kelola yang selama ini sudah dilakukan hingga berdiskusi terkait dengan pengembangan Bukit Kapur Arosbaya kedepan agar bisa dikunjungi banyak wisatawan dan dapat memberikan sumbangsih secara ekonomi kepada warga. Dalam kunjungan ke obyek wisata ini yang letaknya satu kilometer dari perumahan warga masih didapatkan berbagai masalah diantaranya adalah masih minimnya sarana dan prasarana pariwisata di sekitar Bukit Kapur Arosbaya dan masih adanya penambangan aktif di areal Bukit Kapur Arosbaya. 
Beberapa masyarakat yang terlibat dalam kegiatan pengabdian ini mengatakan bahwa kegiatan cukup menarik dan bisa membangkitkan motivasi warga agar peduli dan sadar akan potensi wisata Bukit Kapur Arosbaya yang ada di wilayah mereka. Mereka mengakui cukup terbantu dengan pemetaan potensi wisata melalui SWOT yang didapatkan dalam kegiatan FGD. Hasil analisis SWOT dari Bukit Kapur Arosbaya ditunjukkan pada Tabel 1.

Tabel 1. SWOT Bukit Kapur Arosbaya

\begin{tabular}{|c|c|}
\hline $\begin{array}{l}\text { Strenght (Kekuatan) } \\
\text { 1. Potensi wisata Bukit } \\
\text { Kapur Arosbaya } \\
\text { 2. Akan Segera } \\
\text { disyahkan Bupati } \\
\text { Bangkalan }\end{array}$ & \begin{tabular}{|l} 
Weakness (Kelemahan) \\
1. Akses jalan masih \\
kurang \\
2. Pengelolaan belum \\
terpogram \\
3. Jika hujan akan terjadi \\
banjir \\
4. Sarana dan prasarana \\
yang masih minim \\
5. Sudah terbentuk \\
Kelompok Sadar \\
Wisata (Pokdarwis)
\end{tabular} \\
\hline $\begin{array}{l}\text { Opportunity (Peluang) } \\
\text { 1. } \text { Mengurangi } \\
\text { pengangguran } \\
\text { 2. Pemasukan bagi desa } \\
\text { 3. Parkir, guide, kuliner, } \\
\text { karcis masuk sehingga } \\
\text { ekonomi masyarakat } \\
\text { berputar } \\
\text { 4. Fasilitasi sarana dan } \\
\text { prasarana pendukung } \\
\text { serta mushola }\end{array}$ & 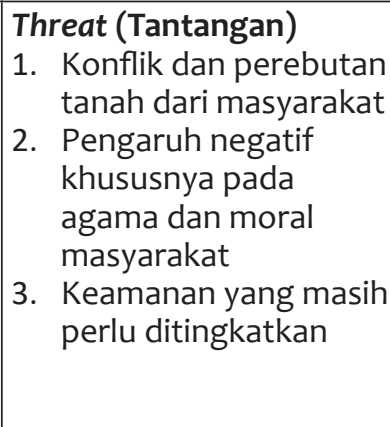 \\
\hline
\end{tabular}

Para peserta menunjukkan antusiasme yang besar terhadap acara ini, terbukti dengan cukup banyaknya pemuda yang datang dalam acara tersebut untuk menambah wawasan dan skill terkait pengembangan potensi wisata Bukit Kapur Arosbaya. Mereka juga cukup aktif bertanya dan menyimak pemaparan materi. Keingintahuan warga masyarakat tentang kegiatan pengelolaan obyek wisata dan pelayanan pariwisata yang besar menunjukkan keinginan dari pengelola wisata di Bukit Kapur Arosbaya untuk berubah menjadi lebih baik. Dalam sesi tanya jawab terdapat beberapa pertanyaan dan berbagi pengalaman masyarakat saat melayani wisatawan yang datang. Dari wawancara peserta sosialisasi dan pelatihan menyatakan bahwa kegiatan dan materi yang diberikan juga tidak membosankan. Hal ini lantaran peserta kegiatan diajak berdialog, melakukan diskusi kelompok hingga melakukan praktek secara langsung terkait memberikan pelayanan prima bagi para wisatawan. Kegiatan interaktif seperti ini baru pertama kali dilakukan di Desa Berbeluk.
Para warga dan pemuda yang mengikuti kegiatan sosialisasi dan pelatihan sadar wista juga sangat antusias, karena sudah mendapatkan transfer of knowledge terkait tata kelola destinasi wisata. Harapannya warga yang ikut pelatihan memiliki kesadaran dan informasi tambahan tentang bagaimana mengelola Bukit Kapur Arosbaya dan bagaimana memberikan pelayanan pada wisatawan yang datang.

\section{KESIMPULAN DAN SARAN}

Program sosialisasi dan pelatihan sadar wisata memberikan menfaat yang cukup besar bagi pemuda dan warga Berbeluk yang berada di sekitar obyek wisata Bukit Kapur Arosbaya. Program ini diharapkan dapat meningkatkan pengetahuan dan skill masyarakat dalam hal pengelolaan sebuah destinasi. Sehingga harapannya kemandirian ekonomi warga bisa ditingkatkan melalui sector pariwisata di desa Berbeluk, Kecamatan Arosbaya, Kabupaten Bangkalan Madura.

Dukungan dari semua lapisan masyarakat diperlukan untuk mengatasi permasalahan terkait pengelolaan obyek wisata Bukit Kapur Arosbaya. selain itu, pemantauan dan pendampingan dari pihak pemerintah Berbeluk, Kecamatan Arosbaya hingga Kabupaten Bangkalan sangat diperlukan untuk mencapai keberlanjutan pengelolaan obyek wisata Bukit Kapur Arosbaya. Pembentukan kelompok sadar wisata (Pokdarwis) juga diperlukan untuk menjadi penggerak pengelolaan obyek wisata Bukit Kapur Arosbaya. Pemberian pelatihan lanjutan mengenai cara pengelolaan obyek wisata juga sangat disarankan supaya hasilnya lebih optimal.

\section{UCAPAN TERIMA KASIH}

Cukup banyak pihak-pihak yang telah membantu selama kegiatan pengabdian masyarakat diDesa Berbeluk, KecamatanArosbaya, Kabupaten Bangkalan. Ucapan terimakasih pada LPPM Universitas Airlangga, dosen dan mahasiswa serta tim pelaksana, pemerintah desa, dan karang taruna Desa Berbeluk

\section{DAFTAR PUSTAKA}

Anonim. 2012. Statistik Pariwisata Indonesia. Jakarta: Kementrian Pariwisata dan Ekonomi Kreatif.

Anonim, Pariwisata Jawa Timur dalam Angka (Surabaya : Dinas Pariwisata Propinsi Jawa Timur, 2007)

BPS, 2014, Provinsi Jawa Timur dalam Angka 
Tahun 2014, Badan Pusat Statistik Jawa Timur. Available from: http://www.bps.go.id/. Diakses pada 13 September 2019.

Pemerintah Indonesia. 2009. Undang-Undang Republik Indonesia Nomor 10 Tahun 2009 tentang Kepariwisataan. Jakarta: Sekretariat Negara.
Prihtiyani, E. 2012. Pertumbuhan Pariwisata Selalu Di Atas Pertumbuhan Ekonomi (The Growth Of Tourism Always Surpasses Economic Growth). Kompas. Available from: http://travel.kompas. com. Diakses pada 10 Oktober 2019 